Ryszard KOWALCZYK

Uniwersytet im. Adama Mickiewicza w Poznaniu

\title{
Strukturyzacja województwa wielkopolskiego jako obszaru badań prasy lokalnej
}

\section{Charakterystyka demograficzna i terytorialna województwa wielkopolskiego}

$\mathbf{R}_{\text {eforma samorządowa } 1990 \text { roku przywróciła miejscowym społecz- }}$ Natomiast nowy trójstopniowy podział terytorialny państwa, wprowadzony z dniem 1 stycznia 1999 roku, wyodrębnił poza gminami dodatkowe ogniwa samorządu terytorialnego na poziomie powiatu i województwa ${ }^{2}$. W ten sposób powstało województwo wielkopolskie o obszarze $29827 \mathrm{~km}^{2}$ (jest to obszar skorygowany, faktyczny, wcześniej bowiem podawano wielkość $29825 \mathrm{~km}^{2}$ ) i liczące wówczas 3346 tys. mieszkańców $^{3}$, w którego skład weszło 226 gmin, 35 powiatów, w tym 31 ziemskich i 4 grodzkie (Kalisz, Konin, Leszno, Poznań) ${ }^{4}$. Ogólną charakterystykę województwa wielkopolskiego z perspektywy podziału terytorialnego i administracyjnego oraz statystycznego na podregiony przedstawiono w tabeli 1.

Na nowe województwo wielkopolskie składało się w całości dawne województwo poznańskie, istniejące do 1998 roku $^{5}$. Ponadto w obręb nowego województwa wielkopolskiego weszły prawie całe dawne województwa: kaliskie, konińskie, leszczyńskie i pilskie, z których tylko nieliczne gminy zostały włączone do województw ościennych. Do no-

1 Ustawa z dnia 8 marca 1990 roku o samorzqdzie terytorialnym (Dz. U. Nr 16, poz. 95).

2 Ustawa z dnia 24 lipca 1998 roku o wprowadzeniu zasadniczego trójstopniowego podzialu terytorialnego państwa (Dz. U. Nr 96, poz. 603).

${ }_{3}$ Administracja samorzadowa oraz jednostki podległe, Urząd Marszałkowski Województwa Wielkopolskiego w Poznaniu, Poznań 1999, s. 9.

4 G. Jabłońska, Nowe prawo samorzqdu terytorialnego, Gdańsk 1999, s. 32 i 64.

5 Przypomnijmy, iż w latach 1975-1998 Polska była podzielona na 49 stosunkowo małych województw. 
$\frac{\sqrt{\frac{\pi}{0}}}{\frac{\pi}{0}}$

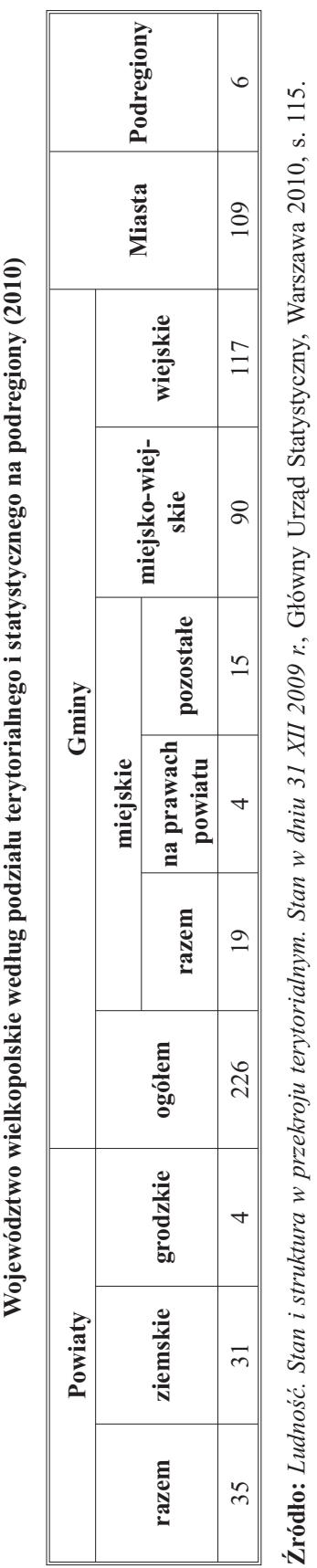


wego województwa wielkopolskiego dołączono również gminy byłych województw: bydgoskiego (gmina Trzemeszno), gorzowskiego (gminy Miedzichowo i Międzychód) oraz zielonogórskiego (gminy Siedlec, Wolsztyn i Zbąszyń) - mapa 1 .

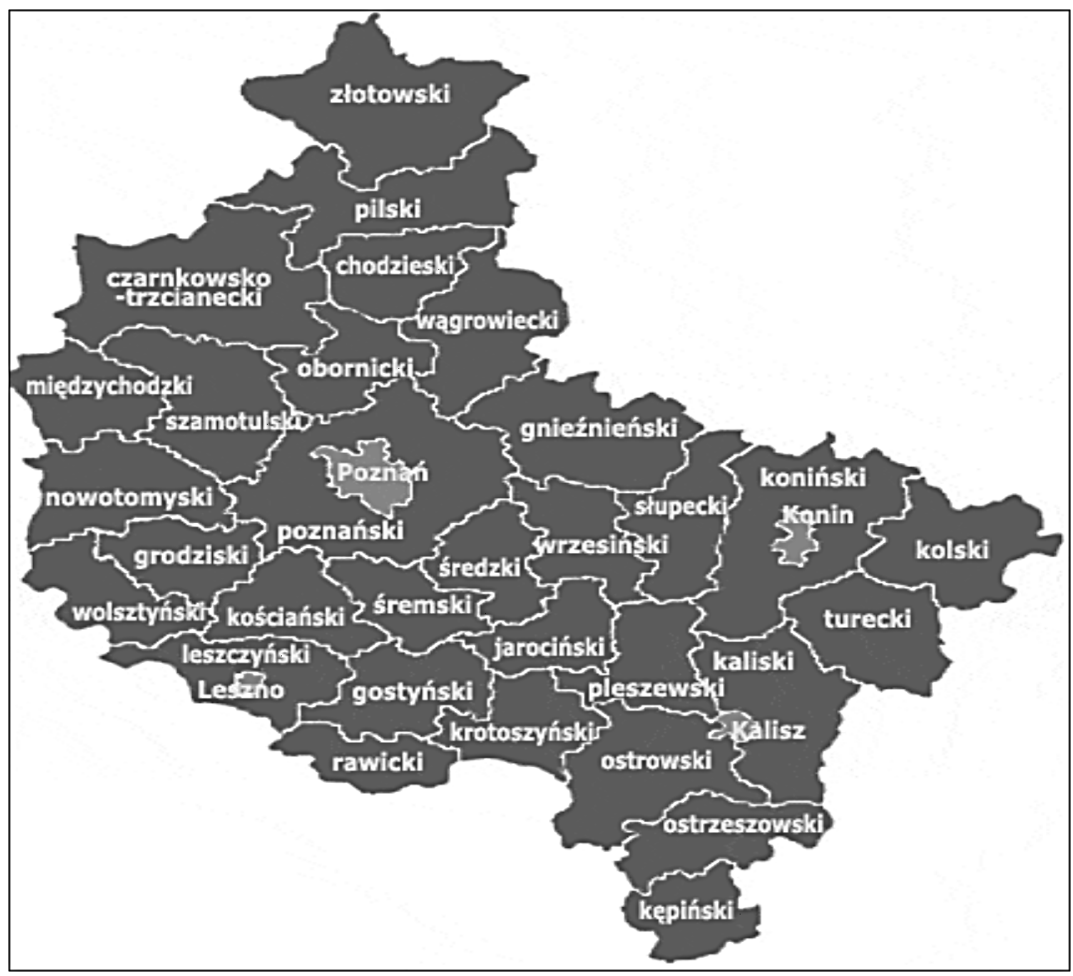

Mapa 1. Współczesne województwo wielkopolskie z podziałem na powiaty (2010)

Województwo wielkopolskie zajmuje drugie miejsce w kraju pod względem powierzchni, zaś trzecie pod względem liczby ludności. Na jego

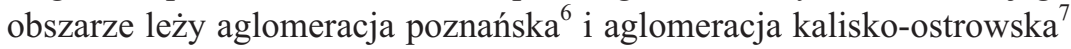

6 Aglomeracja Poznańska została utworzona 15 maja 2007 roku na mocy porozumienia pomiędzy samorządami aglomeracji poznańskiej. Jej skład poszerzono 26 czerwca oraz 28 listopada 2008 roku.

7 Porozumienie o współpracy pomiędzy samorządami aglomeracji kalisko-ostrowskiej podpisano 19 lutego 2008 roku. 
oraz kalisko-ostrowski okręg przemysłowy, konińskie zagłębie węgla brunatnego, poznański okręg przemysłowy.

W 2008 roku w woj. wielkopolskim mieszkało 3397,6 tys. osób ${ }^{8}$. Natomiast na koniec czerwca 2009 roku stan ludności zwiększył się do 3403174 mieszkańców, w tym 1650631 mężczyzn (48,5\%) i 1752543 kobiet $(51,5 \%)^{9}$. W miastach mieszkało 1914130 osób (56,24\%), zaś na wsi 1489044 osób (43,76\%). W skład województwa wielkopolskiego wchodzi 19 gmin miejskich, w tym 4 na prawach powiatu (grodzkie), 90 gmin miejsko-wiejskich oraz 117 gmin wiejskich. W Wielkopolsce jest 109 miast, wśród których prawie połowa liczy mniej niż 5 tys. mieszkańców i jest zamieszkana łącznie przez 143819 osób, czyli 7,51\% ogółu mieszkańców miast (tab. 2).

Tabela 2

Miasta w woj. wielkopolskim według liczby mieszkańców (stan na 30.06.2009)

\begin{tabular}{|c|c|c|c|c|c|c|c|c|}
\hline \multirow[b]{2}{*}{ Ogółem } & \multicolumn{8}{|c|}{ Miasta o liczbie ludności } \\
\hline & $\begin{array}{c}\text { poniżej } \\
2000\end{array}$ & $\begin{array}{c}2000- \\
4999 \\
\end{array}$ & $\begin{array}{c}5000- \\
9999 \\
\end{array}$ & $\begin{array}{r}10000- \\
19999 \\
\end{array}$ & $\begin{array}{c}20000- \\
49999 \\
\end{array}$ & $\begin{array}{c}50000- \\
99999\end{array}$ & $\begin{array}{c}100000 \\
199000\end{array}$ & $\begin{array}{l}200000 \\
\text { i więcej }\end{array}$ \\
\hline \multicolumn{9}{|c|}{ Liczba miast } \\
\hline 109 & 10 & 40 & 21 & 18 & 13 & 5 & 1 & 1 \\
\hline \multicolumn{9}{|c|}{ Liczba ludności miast } \\
\hline 1914130 & 17383 & 126436 & 146992 & 261954 & 337904 & 360610 & 106829 & 556022 \\
\hline
\end{tabular}

Źródło: Ludność. Stan i struktura w przekroju terytorialnym. Stan w dniu 30 VI 2009 r., Główny Urząd Statystyczny, Warszawa 2009, s. 111.

Większość miejscowości wiejskich (z 207 gmin wiejskich i miejsko-wiejskich) liczy mniej niż 7 tys. mieszkańców, natomiast zamieszkuje w nich 617311 osób, czyli 32,25\% ogółu mieszkańców wsi (tab. 3).

Wśród 90 gmin miejsko-wiejskich aż 71 (79\%) liczy od 5000 do 19999 mieszkańców, w których zamieszkuje łącznie 764428 osób, czyli 58\% ogółu mieszkańców gmin miejsko-wiejskich (tab. 4).

8 Polska w liczbach, Główny Urząd Statystyczny, Warszawa 2009, s. 3.

9 Ludność. Stan i struktura w przekroju terytorialnym. Stan w dniu 30 VI 2009 r., Główny Urząd Statystyczny, Warszawa 2009, s. 12. 
Tabela 3

Gminy wiejskie i miejsko-wiejskie w woj. wielkopolskim według liczby mieszkańców wsi (stan na 30.06.2009)

\begin{tabular}{||c|c|c|c|c|c||}
\hline \multirow{2}{*}{ Ogółem } & \multicolumn{5}{|c||}{ Gminy o liczbie ludności } \\
\cline { 2 - 6 } & poniżej 2 000 & $\mathbf{2} 000-4999$ & $\mathbf{5 0 0 0 - 6 ~ 9 9 9}$ & $\mathbf{7 0 0 0 - 9 9 9 9}$ & $\mathbf{1 0} 000$ i więcej \\
\hline \multicolumn{7}{|c||}{ Liczba gmin wiejskich i miejsko-wiejskich } \\
\hline 207 & - & 53 & 69 & 54 & 31 \\
\hline \multicolumn{7}{|c|}{ Liczba ludności wsi w gminach wiejskich i miejsko-wiejskich } \\
\hline 1489044 & - & 208098 & 409213 & 449511 & 422222 \\
\hline
\end{tabular}

Źródło: Ludność. Stan i struktura w przekroju terytorialnym. Stan w dniu 30 VI 2009 r., Główny Urząd Statystyczny, Warszawa 2009, s. 112.

Tabela 4

Gminy miejsko-wiejskie w woj. wielkopolskim według liczby mieszkańców

(stan na 30.06.2009)

\begin{tabular}{||c|c|c|c|c|c||}
\hline \multirow{2}{*}{ Ogółem } & \multicolumn{6}{|c||}{ Gminy o liczbie ludności } \\
\cline { 2 - 7 } & poniżej 2 000 & $\mathbf{2 0 0 0 - 4 9 9 9}$ & $\mathbf{5 0 0 0 - 9 9 9 9}$ & $\mathbf{1 0} 000-\mathbf{1 9} 999$ & $\mathbf{2 0} 000-\mathbf{4 9} 999$ \\
\hline \multicolumn{7}{|c||}{ Liczba gmin } \\
\hline 90 & - & 2 & 38 & 33 & 17 \\
\hline \multicolumn{7}{|c|}{ Liczba ludności gmin } \\
\hline 1317637 & - & 9106 & 298187 & 466241 & 544103 \\
\hline
\end{tabular}

Źródlo: Ludność. Stan i struktura w przekroju terytorialnym. Stan w dniu 30 VI 2009 r., Główny Urząd Statystyczny, Warszawa 2009, s. 113.

W tabeli 5 pokazano podział ludności województwa wielkopolskiego według płci i miejsca zamieszkania w poszczególnych powiatach.

\section{Województwo wielkopolskie według podregionów}

Stosowany w naszym kraju podział NTS (Nomenklatura Jednostek Terytorialnych do celów Statystycznych), który jest odpowiednikiem europejskiego systemu statystycznego NUTS (Nomenclature of Units Territorial for Statistics) ${ }^{10}$, umożliwił wyodrębnienie na obszarze Polski

10 Statystyczne jednostki terytorialne wprowadzono w Unii Europejskiej w 1988 roku, a ich celem była harmonizacja i usprawnienie realizacji polityki regionalnej. Według tych jednostek zbierane są dane statystyczne przez Europejski Urząd Statystyczny (EUROSTAT), które stanowią podstawę alokacji środków rozwojowych i pomocowych UE, przeznaczonych w szczególności na rozwój regionów. 
$\frac{\sqrt{6}}{\frac{\pi}{2}}$

\begin{tabular}{|c|c|c|c|c|c|c|c|c|c|c|c|c|c|c|c|c|c|c|c|}
\hline & $\begin{array}{l}\frac{2}{0} \\
\frac{0}{2} \\
\frac{0}{2}\end{array}$ & $\stackrel{0}{0}$ & $\begin{array}{l}\infty \\
0 \\
0 \\
0\end{array}$ & 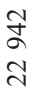 & $\begin{array}{l}n \\
\text { ñ } \\
\sim\end{array}$ & 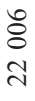 & $\begin{array}{l}\infty \\
m \\
n \\
n\end{array}$ & $\begin{array}{l}\infty \\
\text { ஸె } \\
\text { त }\end{array}$ & $\begin{array}{l}\stackrel{0}{0} \\
+ \\
\text { ச }\end{array}$ & $\begin{array}{l}\bar{b} \\
\text { ڤ } \\
\stackrel{N}{N}\end{array}$ & $\frac{a}{n}$ & $\begin{array}{l}\vec{\gamma} \\
\stackrel{+}{~} \\
\stackrel{\sim}{ }\end{array}$ & 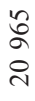 & $\begin{array}{l}\infty \\
\infty \\
n\end{array}$ & $\begin{array}{l}\stackrel{ }{\mathrm{f}} \\
\stackrel{\sim}{N} \\
\stackrel{N}{ }\end{array}$ & $\frac{\infty}{\infty}$ & $\begin{array}{l}\text { mे } \\
\text { }\end{array}$ & 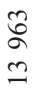 & $\begin{array}{l}\stackrel{\sim}{\sim} \\
\underset{\sim}{\sim}\end{array}$ \\
\hline$\frac{a}{2}$ & 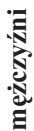 & $a$ & $\begin{array}{l}\text { 음 } \\
\stackrel{+}{+}\end{array}$ & $\begin{array}{l}\stackrel{ \pm}{\sim} \\
\text { }\end{array}$ & 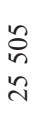 & $\frac{\infty}{\stackrel{\infty}{\sigma}}$ & $\begin{array}{l}n \\
n \\
n\end{array}$ & $\begin{array}{l}\text { す } \\
\text { त }\end{array}$ & $\begin{array}{l}N \\
\text { ñ } \\
\text { ñ }\end{array}$ & 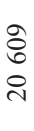 & $\begin{array}{l}\stackrel{\infty}{\infty} \\
\text { N } \\
\text { N }\end{array}$ & $\begin{array}{l}\bar{b} \\
n \\
n\end{array}$ & $\begin{array}{l}\text { ָे } \\
\infty \\
\text { లి }\end{array}$ & \begin{tabular}{l}
\multirow{\infty}{\infty}{} \\
n \\
$n$
\end{tabular} & $\begin{array}{l}= \\
\text { N } \\
\text { N }\end{array}$ & $\begin{array}{l}0 \\
+ \\
\infty \\
a\end{array}$ & $\begin{array}{l}\overrightarrow{\hat{\infty}} \\
\infty\end{array}$ & $\begin{array}{l}0 \\
0 \\
\pm\end{array}$ & $\begin{array}{l}\text { N } \\
\text { N }\end{array}$ \\
\hline & Е & $\infty$ & $\begin{array}{l}n \\
\tilde{n} \\
\stackrel{N}{N}\end{array}$ & $\begin{array}{l}0 \\
\text { O } \\
\text { \& } \\
\text { o }\end{array}$ & 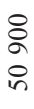 & $\begin{array}{l}+ \\
\text { a } \\
\stackrel{m}{q}\end{array}$ & $\begin{array}{l}\bar{a} \\
\infty \\
\infty\end{array}$ & 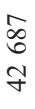 & $\frac{N}{n}$ & $\begin{array}{l}\stackrel{2}{\approx} \\
7\end{array}$ & $\begin{array}{l}\stackrel{2}{2} \\
\text { ஸे }\end{array}$ & $\begin{array}{l}\text { No } \\
\text { م } \\
0\end{array}$ & $\begin{array}{l}\stackrel{g}{\gamma} \\
7\end{array}$ & $\stackrel{\bar{N}}{\stackrel{n}{r}}$ & $\begin{array}{l}\bar{\sigma} \\
\text { o }\end{array}$ & $\begin{array}{l}\text { สิ } \\
\text { a }\end{array}$ & $\begin{array}{l}\stackrel{0}{\sim} \\
\stackrel{\sim}{N} \\
\infty\end{array}$ & $\begin{array}{l}\frac{a}{a} \\
\text { ㄱ }\end{array}$ & 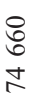 \\
\hline & $\begin{array}{l}\frac{2}{0} \\
\frac{0}{0} \\
\frac{0}{2}\end{array}$ & $r$ & $\begin{array}{l}\widehat{6} \\
\pm\end{array}$ & $\begin{array}{l}\bar{\Omega} \\
\text { হ }\end{array}$ & \begin{tabular}{l} 
\pm \\
\multirow{\sigma}{*}{} \\
$\dot{y}$
\end{tabular} & $\begin{array}{l}\stackrel{8}{\circ} \\
\qquad \\
0\end{array}$ & $\frac{\mathfrak{N}}{\mathrm{N}}$ & 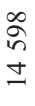 & $\frac{\bar{\infty}}{\infty}$ & $\frac{0}{n}$ & $\begin{array}{l}n \\
2 \\
-1\end{array}$ & $\frac{n}{a}$ & $\begin{array}{l}\text { ㅇ } \\
\text { ல } \\
\text { a }\end{array}$ & $\begin{array}{l}\text { ㅈ } \\
\stackrel{\sim}{\sim}\end{array}$ & $\begin{array}{l}\bar{\Im} \\
\stackrel{y}{N}\end{array}$ & $\underset{\infty}{\infty}$ & $\begin{array}{l}\curvearrowleft \\
\infty \\
1\end{array}$ & $\begin{array}{l}\mho \\
\infty \\
\Xi\end{array}$ & $\begin{array}{l}\text { I } \\
\text { J }\end{array}$ \\
\hline
\end{tabular}

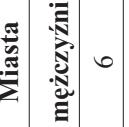

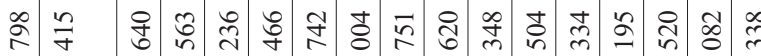

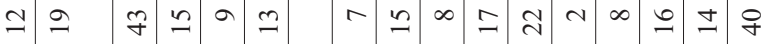

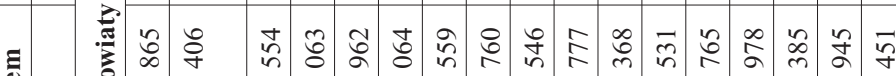
I

.

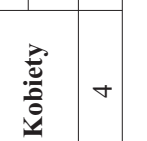

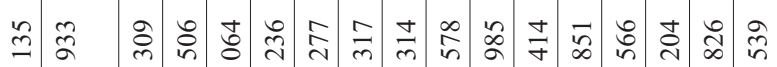

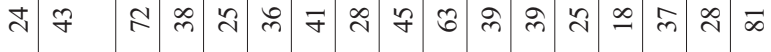

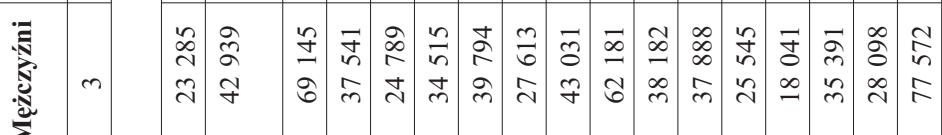

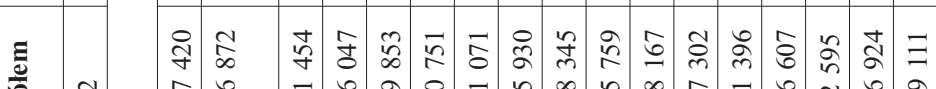

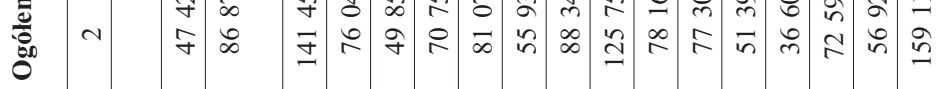




\begin{tabular}{|c|c|c|c|c|c|c|c|c|c|c|c|c|c|c|c|c|c|c|c|c|c|}
\hline 으 & $\begin{array}{l} \pm \\
\infty \\
\infty\end{array}$ & $\begin{array}{l}\hat{n} \\
\infty \\
\approx\end{array}$ & 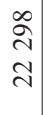 & $\begin{array}{l}\infty \\
\gamma \\
2 \\
\alpha\end{array}$ & $\left|\begin{array}{l}\infty \\
0 \\
\sim \\
n\end{array}\right|$ & $\begin{array}{l}\stackrel{2}{+} \\
\stackrel{2}{\sim}\end{array}$ & 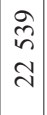 & $\begin{array}{l}n \\
2 \\
\tilde{2}\end{array}$ & 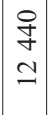 & $\begin{array}{l}\Delta \\
\vec{\sim} \\
i\end{array}$ & $\begin{array}{l}2 \\
\infty \\
\infty \\
=\end{array}$ & $\begin{array}{l}\bar{\Xi} \\
\bar{\tau}\end{array}$ & $\begin{array}{l}\infty \\
a \\
\underline{z}\end{array}$ & $\begin{array}{l}0 \\
\infty \\
0 \\
0\end{array}$ & $\begin{array}{l}\text { 点 } \\
\text { 采 }\end{array}$ & & I & 1 & 1 & 1 & 1 \\
\hline$a$ & $\begin{array}{l}\infty \\
\infty \\
\infty \\
\infty \\
0\end{array}$ & 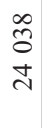 & 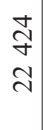 & $\frac{\infty}{\infty}$ & 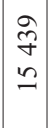 & $\begin{array}{l}\hat{b} \\
\infty \\
\curvearrowright\end{array}$ & 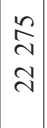 & $\mid \begin{array}{l} \pm \\
n \\
n \\
0 \\
-1\end{array}$ & $\begin{array}{l}n \\
n \\
\simeq\end{array}$ & $\begin{array}{l}\infty \\
\infty \\
\infty \\
\dot{\sim}\end{array}$ & $\begin{array}{l}\mathfrak{2} \\
\infty \\
\simeq\end{array}$ & $\begin{array}{l}\bar{\infty} \\
0 \\
\bar{N}\end{array}$ & $\begin{array}{l}0 \\
0 \\
0 \\
=\end{array}$ & $\begin{array}{l}\infty \\
\sim \\
n \\
\text { ㄱ }\end{array}$ & 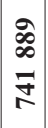 & & I & 1 & 1 & 1 & 1 \\
\hline$\infty$ & $\begin{array}{l}\mathbb{N} \\
b \\
0 \\
n\end{array}$ & \begin{tabular}{l}
2 \\
$\infty$ \\
\multirow{\gamma}{*}{}
\end{tabular} & 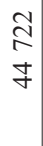 & $\begin{array}{l}\infty \\
\infty \\
\hat{n} \\
\infty\end{array}$ & $\begin{array}{l}\tilde{f} \\
0 \\
0 \\
\tilde{n}\end{array}$ & $\begin{array}{l}\frac{0}{6} \\
\frac{7}{7}\end{array}$ & $\begin{array}{l}\searrow \\
\infty \\
\forall \\
\forall\end{array}$ & $\begin{array}{l}\tilde{f} \\
m \\
m \\
m\end{array}$ & 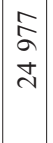 & $\begin{array}{l}2 \\
\delta \\
0 \\
i\end{array}$ & $\begin{array}{l}8 \\
2 \\
n \\
m\end{array}$ & $\begin{array}{l}\mathcal{I} \\
\mathcal{I} \\
\mathcal{J}\end{array}$ & $\begin{array}{l}\tilde{N} \\
n \\
n \\
m\end{array}$ & $\begin{array}{l}\underset{J}{J} \\
\underset{m}{ }\end{array}$ & 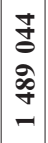 & & 1 & 1 & 1 & 1 & 1 \\
\hline$r$ & $\begin{array}{l}\infty \\
\stackrel{q}{q} \\
a\end{array}$ & 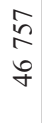 & $\frac{\bar{a}}{a}$ & 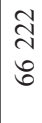 & 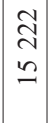 & 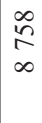 & 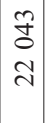 & $\begin{array}{l}n \\
\infty \\
n \\
=\end{array}$ & $\begin{array}{l}\stackrel{I}{I} \\
\simeq\end{array}$ & $\begin{array}{l}0 \\
8 \\
1 \\
=\end{array}$ & $\begin{array}{l}\hat{a} \\
0\end{array}$ & $\begin{array}{c}\bar{\infty} \\
0 \\
r\end{array}$ & 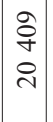 & $\begin{array}{l}n \\
\delta \\
\infty \\
=\end{array}$ & $\begin{array}{l}\hat{b} \\
\infty \\
12 \\
\text { in }\end{array}$ & & $\begin{array}{l}\vec{J} \\
i n\end{array}$ & $\begin{array}{l}\hat{\imath} \\
\xi\end{array}$ & $\begin{array}{l}\stackrel{2}{2} \\
\text { m}\end{array}$ & $\begin{array}{l}\hat{8} \\
\text { 원 }\end{array}$ & $\begin{array}{l}\frac{a}{i n} \\
\text { iे }\end{array}$ \\
\hline 0 & $\begin{array}{l}\hat{\sigma} \\
\infty\end{array}$ & $\begin{array}{l}\tilde{z} \\
\text { テ } \\
\text { J }\end{array}$ & $\begin{array}{l}\underset{\gamma}{\forall} \\
\infty\end{array}$ & ले & $\begin{array}{l} \pm \\
\sigma \\
m\end{array}$ & $\stackrel{\infty}{\stackrel{\infty}{\infty}}$ & 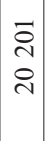 & $\mid \begin{array}{l}2 \\
\stackrel{0}{n} \\
0 \\
0\end{array}$ & 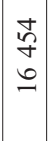 & $\begin{array}{l} \pm \\
\hat{\sigma} \\
\end{array}$ & 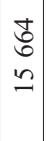 & 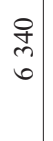 & $\begin{array}{l}0 \\
\infty \\
\infty\end{array} \mid$ & 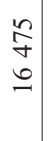 & $\frac{8}{i n}$ & 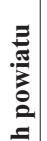 & $\mid \begin{array}{l}\infty \\
\infty \\
\stackrel{2}{2} \\
\stackrel{\gamma}{+}\end{array}$ & $\begin{array}{l}a \\
\hat{a} \\
\hat{m}\end{array}$ & \begin{tabular}{l}
$\tilde{N}$ \\
$\tilde{n}$ \\
\multirow{n}{n}{}
\end{tabular} & $\begin{array}{l}\hat{n} \\
\sim \\
\infty \\
\curvearrowleft \\
\sim\end{array}$ & $\frac{\infty}{\infty}$ \\
\hline in & $\begin{array}{l}\stackrel{n}{\simeq} \\
\infty\end{array}$ & $\begin{array}{l}\text { ¿ } \\
\text { م) } \\
\infty\end{array}$ & $\begin{array}{l}\text { రి } \\
\text { ర } \\
\text { - }\end{array}$ & $\begin{array}{l}\overline{0} \\
\stackrel{n}{\Xi}\end{array}$ & $\left|\begin{array}{l}0 \\
2 \\
\grave{\lambda}\end{array}\right|$ & $\begin{array}{l}\stackrel{0}{2} \\
\hat{\sigma}\end{array}$ & $\begin{array}{l}\mathcal{J} \\
\underset{J}{J} \\
\text { f }\end{array}$ & $\begin{array}{l}\vec{D} \\
\dot{\infty} \\
\vec{N}\end{array}$ & 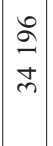 & $\begin{array}{l}0 \\
6 \\
m \\
m\end{array}$ & $\begin{array}{c}\vec{b} \\
m \\
\tilde{m} \\
m\end{array}$ & $\begin{array}{l}\overrightarrow{\mathcal{y}} \\
\tilde{2}\end{array}$ & 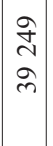 & $\begin{array}{c}8 \\
\infty \\
\sim \\
\dot{m} \\
m\end{array}$ & 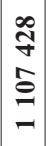 & 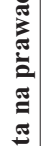 & $\begin{array}{c}\stackrel{1}{0} \\
\infty \\
ః \\
\varrho\end{array}$ & $\begin{array}{l}\text { तु } \\
2 \\
\curvearrowright\end{array}$ & $\begin{array}{l}\text { ते } \\
\text { ț }\end{array}$ & $\begin{array}{l}\text { ปี } \\
0 \\
0 \\
n \\
n\end{array}$ & 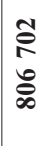 \\
\hline+ & $\begin{array}{l}\sim \\
\infty \\
\sim\end{array}$ & $\begin{array}{l}8 \\
0 \\
0\end{array}$ & $\begin{array}{l}\stackrel{\infty}{+} \\
\stackrel{\infty}{\infty}\end{array}$ & $\begin{array}{l}0 \\
\text { o } \\
\sigma \\
-\end{array}$ & $\begin{array}{c}0 \\
\tilde{m} \\
f \\
0 \\
\tilde{n}\end{array}$ & $\begin{array}{l}\overline{0} \\
\text { กิ }\end{array}$ & $\begin{array}{l}c \\
\infty \\
i \\
\forall \\
\forall\end{array}$ & $\begin{array}{c}\infty \\
\stackrel{\infty}{=} \\
\infty \\
\sim\end{array}$ & $\begin{array}{l}\infty \\
\infty \\
0 \\
\infty\end{array} \mid$ & $\begin{array}{l}\mathscr{D} \\
\infty \\
\mathcal{H} \\
\mathcal{\gamma}\end{array}$ & $\begin{array}{l}\tilde{N} \\
\tilde{n} \\
\tilde{m}\end{array}$ & 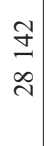 & $\begin{array}{l}\hat{N} \\
\infty \\
\infty \\
ల\end{array} \mid$ & $\begin{array}{l}\vec{尺} \\
\dot{m}\end{array}$ & $\begin{array}{l}\tilde{\Xi} \\
\tilde{\Xi} \\
\tilde{\Xi} \\
\tilde{2}\end{array}$ & $\stackrel{\vec{m}}{\Sigma}$ & $\begin{array}{l}\vec{J} \\
\hat{n}\end{array}$ & $\begin{array}{l}\tilde{Q} \\
F \\
F\end{array}$ & $\begin{array}{l}\stackrel{2}{R} \\
\text { m}\end{array}$ & $\begin{array}{l}\text { ठे } \\
\text { o } \\
\hat{2}\end{array}$ & $\begin{array}{l}\frac{a}{2} \\
\text { ì } \\
\text { \% }\end{array}$ \\
\hline$m$ & $\begin{array}{l}\tilde{n} \\
\tilde{o} \\
\hat{\sim}\end{array}$ & $\begin{array}{l}2 \\
\infty \\
2 \\
0 \\
0\end{array}$ & $\begin{array}{l}n \\
\infty \\
\infty \\
\infty\end{array}$ & $\begin{array}{l}a \\
n \\
n \\
n\end{array}$ & $\begin{array}{l}n \\
\tilde{n} \\
\tilde{\nu}\end{array} \mid$ & $\begin{array}{l}\mathfrak{2} \\
8 \\
2\end{array}$ & $\begin{array}{l}\stackrel{0}{\sim} \\
\stackrel{+}{7} \\
\text { f }\end{array}$ & $\begin{array}{l}\hat{b} \\
0 \\
\hat{\imath}\end{array}$ & $\begin{array}{l}\bar{\alpha} \\
\infty \\
\alpha\end{array}$ & $\begin{array}{l}\hat{2} \\
\infty \\
0 \\
\dot{f}\end{array}$ & $\begin{array}{l}2 \\
\infty \\
m \\
m\end{array}$ & 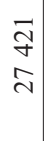 & $\begin{array}{l}f \\
f \\
f \\
0 \\
m\end{array} \mid$ & $\begin{array}{c}\tilde{\delta} \\
8 \\
\dot{m}\end{array}$ & 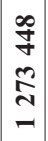 & & $\begin{array}{l}\infty \\
\infty \\
\sim \\
g \\
q\end{array}$ & $\mid \begin{array}{l}a \\
\hat{a} \\
\hat{n}\end{array}$ & \begin{tabular}{l}
$\tilde{N}$ \\
$\tilde{n}$ \\
\multirow{n}{n}{}
\end{tabular} & $\begin{array}{l}\Re \\
\tilde{2} \\
\infty \\
\sim\end{array}$ & $\frac{\infty}{n}$ \\
\hline$N$ & $\begin{array}{l}\tilde{J} \\
\infty \\
\dot{\sim}\end{array}$ & $\begin{array}{l}\stackrel{2}{n} \\
\stackrel{2}{2}\end{array}$ & 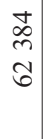 & $\frac{i n}{\frac{n}{n}}$ & $\begin{array}{l}m \\
\infty \\
\alpha \\
2\end{array}$ & $\begin{array}{l}0 \\
i \\
\infty \\
\infty \\
n\end{array}$ & $\mid \begin{array}{c}\infty \\
0 \\
\vdots \\
\infty\end{array}$ & $\begin{array}{l}\vec{J} \\
i \\
n \\
n\end{array}$ & $\begin{array}{l}m \\
a \\
i n\end{array}$ & $\mid \begin{array}{l}\hat{2} \\
\hat{2} \\
\infty\end{array}$ & $\begin{array}{l}= \\
m \\
\infty \\
0\end{array}$ & $\begin{array}{l}n \\
i \\
n \\
n\end{array}$ & 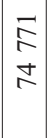 & $\begin{array}{l}\mathbb{2} \\
⿱ \\
\infty \\
0 \\
0\end{array}$ & 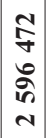 & & 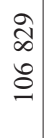 & $\begin{array}{l}\text { तु } \\
2 \\
\curvearrowright\end{array}$ & $\begin{array}{l}\overparen{ત} \\
\text { ปt }\end{array}$ & $\begin{array}{l}\text { ป̂ } \\
0 \\
0 \\
\curvearrowleft \\
n\end{array}$ & 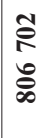 \\
\hline- & 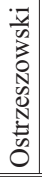 & $\frac{\frac{\vec{u}}{\omega}}{\vec{n}}$ & $\begin{array}{l}\frac{\bar{y}}{w} \\
\vec{v} \\
\bar{N} \\
\tilde{w} \\
\frac{\omega}{a}\end{array}$ & 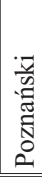 & 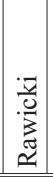 & 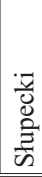 & 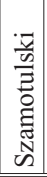 & 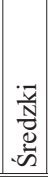 & 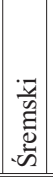 & $\mid$\begin{tabular}{l|}
$\vec{z}$ \\
$\bar{u}$ \\
$\stackrel{\Xi}{\Xi}$ \\
$\vec{\theta}$
\end{tabular} & 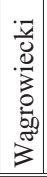 & 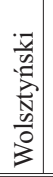 & 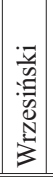 & $\mid \begin{array}{c}\frac{\bar{z}}{0} \\
\frac{3}{0} \\
\frac{0}{0} \\
\frac{0}{N} \\
\end{array}$ & 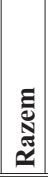 & & 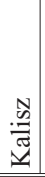 & 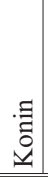 & 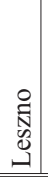 & 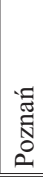 & 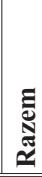 \\
\hline
\end{tabular}


pięciu poziomów, w tym trzech poziomów tzw. regionalnych oraz dwu lokalnych ${ }^{11}$ :

a) poziom regionalny: 1$)$ makroregiony ${ }^{12}$ (6 jednostek NTS1), 2) regiony ${ }^{13}$ - województwa (16 jednostek NTS2), 3 ) podregiony ${ }^{14}$ (66 jednostek NTS3) oraz

b) poziom lokalny: 4) powiaty i miasta na prawach powiatu (łącznie 379 jednostek NTS4, w tym 314 jednostek powiatowych - powiatów ziemskich i 65 jednostek - miast na prawach powiatu, czyli powiatów grodzkich) i 5) gminy (2479 jednostek NTS5, w tym 65 miast na prawach powiatu) ${ }^{15}$. Poziom lokalny określa się jako Local Administrative Units (LAU). W Polsce w ramach tego podziału statystycznego wyodrębniono dwa wymienione wyżej poziomy lokalne, czyli powiatowy (LAU1) oraz gminny (LAU2).

Województwo wielkopolskie zaliczone jest do tzw. makroregionu regionu północno-zachodniego ${ }^{16}$ i zostało podzielone na 6 podregionów (NUTS3): kaliski, koniński, leszczyński, pilski, poznański, miasto Poznań $^{17}$ (mapa 2).

Statystyczny obraz podregionów województwa wielkopolskiego według liczby i struktury ludności przedstawiono w tabeli 6. Podregion kaliski jest najbardziej zaludnionym podregionem województwa wielkopolskiego. W następnej kolejności znajdują się podregiony: koniński, poznański, miasto Poznań, leszczyński i pilski (posiada on także najmniejszą gęstość zaludnienia).

11 Dane na dzień 31 grudnia 2009 roku według: Ludność. Stan i struktura w przekroju terytorialnym. Stan w dniu 31 XII 2009 r., Główny Urząd Statystyczny, Warszawa 2010, s. 115.

12 Na poziomie NTS1, czyli makroregionu liczba mieszkańców powinna mieścić się między $3 \mathrm{mln}$ a $7 \mathrm{mln}$.

13 Na poziomie NTS2, czyli w regionie (województwie) powinno mieszkać od $0,8 \mathrm{mln}$ do $3 \mathrm{mln}$ ludności.

$14 \mathrm{Na}$ poziomie NTS3, czyli w podregionie powinno mieszkać od $0,15 \mathrm{mln}$ do 0,8 mln ludności.

15 Stan na 1 stycznia 2010 roku.

16 W skład regionu północno-zachodniego (NTS1) wchodzą województwa lubuskie, wielkopolskie i zachodniopomorskie.

17 Rozporządzenie Rady Ministrów z dnia 14 listopada 2007 roku w sprawie wprowadzenia Nomenklatury Jednostek Terytorialnych do Celów Statystycznych (NTS) - Dz. U. 2007, Nr 214, poz. 1573. W nomenklaturze statystycznej w Polsce używa się skrótu NTS, czyli Nomenklatura Jednostek Terytorialnych do Celów Statystycznych. 


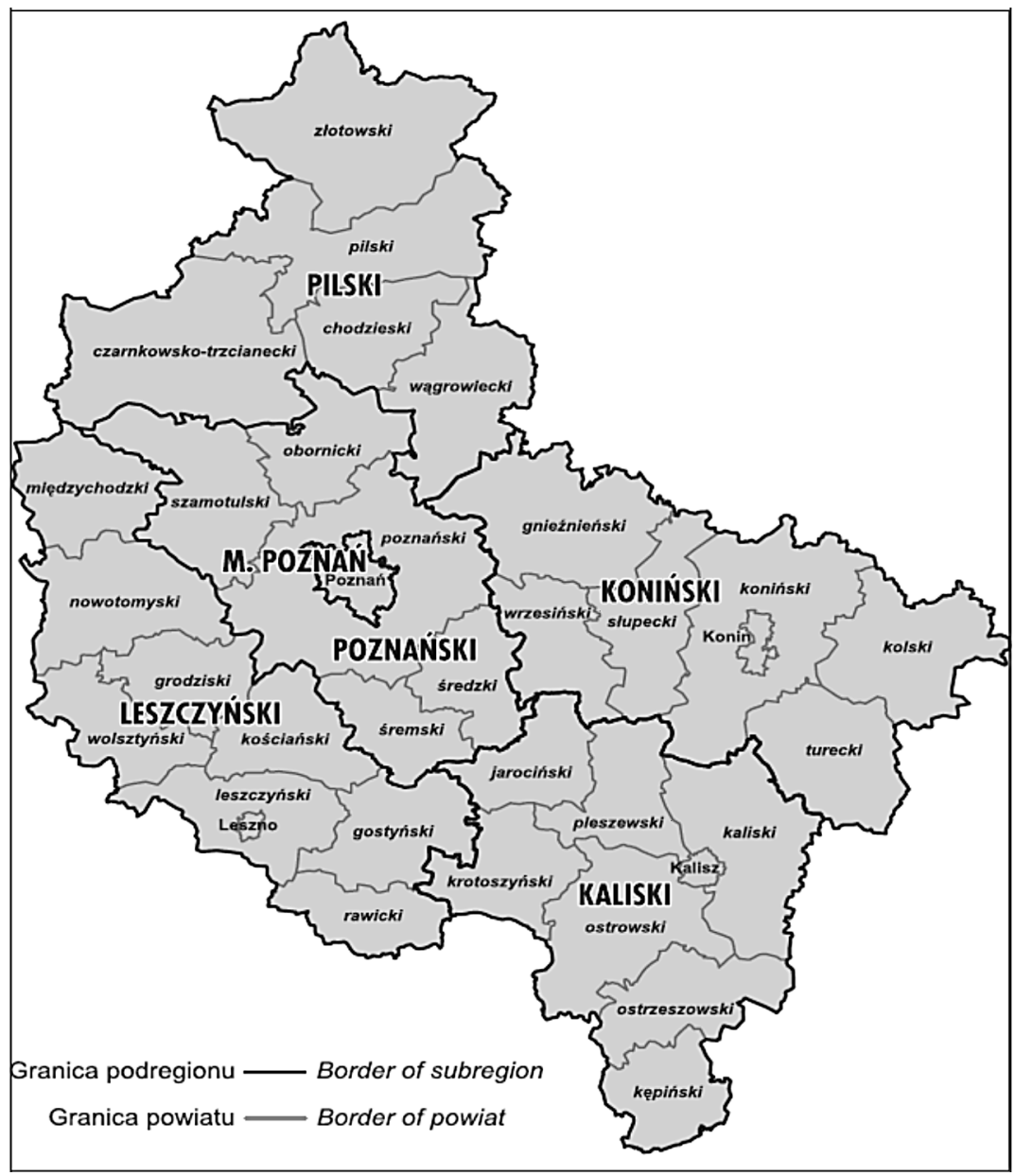

Mapa 2. Współczesne województwo wielkopolskie z podziałem na podregiony i powiaty (2010)

Źródło: Biuletyn Statystyczny Województwa Wielkopolskiego. IV kwartat 2009, Urząd Statystyczny w Poznaniu, Poznań luty 2010, s. 70.

Jeszcze bogatszy obraz mieszkańców poszczególnych podregionów województwa wielkopolskiego wyłania się z podziału ludności według takich specyficznych kategorii wiekowych, jak wiek przedprodukcyjny (0-17 lat), produkcyjny (mężczyźni 18-64 lata, kobiety 18-59 lat) i poprodukcyjny (mężczyźni 65 lat i więcej, kobiety 60 lat i więcej) - tabela 7. 


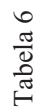

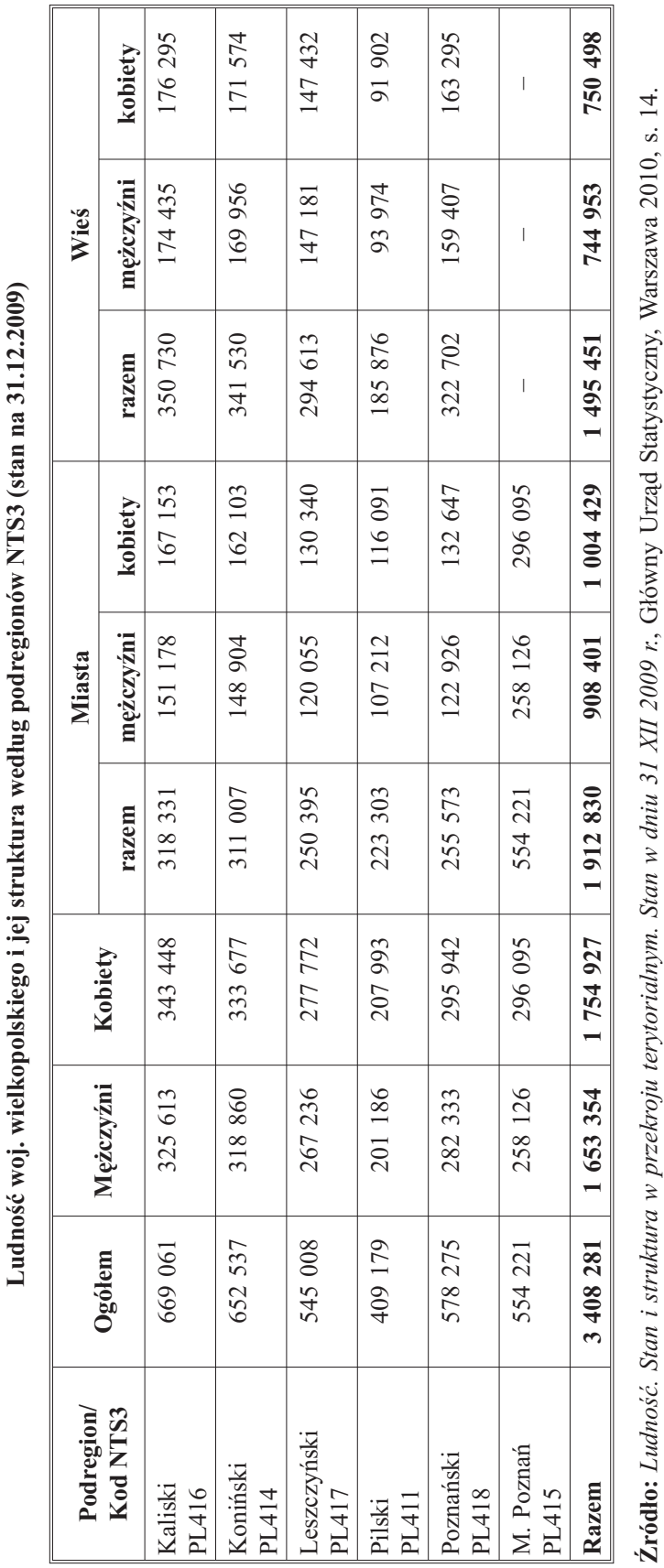


Warto zauważyć, iż najniższym wskaźnikiem ludności w wieku nieprodukcyjnym wykazują się dwa podregiony, w kolejności miasto Poznań i poznański. Natomiast najwyższe wskaźniki mają podregiony kaliski i koniński.

Tabela 7

Ludność woj. wielkopolskiego w wieku produkcyjnym i nieprodukcyjnym według podregionów NTS3 (stan na 30.06.2009)

\begin{tabular}{|c|c|c|c|c|c|c|c|}
\hline \multirow{3}{*}{$\begin{array}{l}\text { Podregion/ } \\
\text { Kod NTS3 }\end{array}$} & \multirow{3}{*}{ Ogólem } & \multicolumn{6}{|c|}{ W wieku } \\
\hline & & \multirow{2}{*}{$\begin{array}{c}\text { przedpro- } \\
\text { dukcyj- } \\
\text { nym }^{1}\end{array}$} & \multicolumn{3}{|c|}{ produkcyjnym $^{2}$} & \multirow{2}{*}{$\begin{array}{l}\text { popro- } \\
\text { duk- } \\
\text { cyjnym }\end{array}$} & \multirow{2}{*}{$\begin{array}{c}\text { nieproduk- } \\
\text { cyjnym na } 100 \\
\text { osób w wieku } \\
\text { produkcyjnym }\end{array}$} \\
\hline & & & razem & $\begin{array}{c}\text { mobil- } \\
\text { nym }^{3}\end{array}$ & $\begin{array}{l}\text { niemo- } \\
\text { bilnym }^{4}\end{array}$ & & \\
\hline $\begin{array}{l}\text { Kaliski } \\
\text { PL416 }\end{array}$ & 668225 & 137144 & 428273 & 269106 & 159167 & 102808 & 56 \\
\hline $\begin{array}{l}\text { Koniński } \\
\text { PL414 }\end{array}$ & 652226 & 137063 & 418544 & 264158 & 154386 & 96619 & 56 \\
\hline $\begin{array}{l}\text { Leszczyński } \\
\text { PL417 }\end{array}$ & 544240 & 117394 & 351585 & 222995 & 128590 & 75261 & 55 \\
\hline $\begin{array}{l}\text { Pilski } \\
\text { PL411 }\end{array}$ & 408906 & 88202 & 264938 & 165563 & 99375 & 55766 & 54 \\
\hline $\begin{array}{l}\text { Poznański } \\
\text { PL418 }\end{array}$ & 573555 & 122780 & 378571 & 242958 & 135613 & 72204 & 52 \\
\hline $\begin{array}{l}\text { M. Poznań } \\
\text { PL415 }\end{array}$ & 556022 & 84695 & 368842 & 234740 & 134102 & 102485 & 51 \\
\hline
\end{tabular}

${ }^{1}$ 0-17 lat; ${ }^{2}$ mężczyźni 18-64 lata, kobiety $18-59$ lat; ${ }^{3} 18-44$ lata; ${ }^{4}$ mężczyźni $45-64$ lata, kobiety 45-59 lat; ${ }^{5}$ mężczyźni 65 lat i więcej, kobiety 60 lat i więcej.

Źródło: Ludność. Stan i struktura w przekroju terytorialnym. Stan w dniu 30 VI 2009 r., Główny Urząd Statystyczny, Warszawa 2009, s. 20.

Największy wskaźnik zatrudnienia (na 1000 mieszkańców) odnotowują następujące podregiony: miasto Poznań, poznański oraz kaliski i leszczyński. Natomiast najmniejszym wskaźnikiem zatrudnienia wykazują się podregiony koniński i pilski. Wpływ na to posiada zarówno wskaźnik inicjatywy gospodarczej (liczba podmiotów gospodarczych na 1000 mieszkańców), jak i skala rozwoju sektora usług rynkowych (handel hurtowy i detaliczny, naprawa pojazdów samochodowych, motocykli oraz artykułów użytku osobistego i domowego, hotele i restauracje, transport, gospodarka magazynowa i łączność, pośrednictwo finansowe, obsługa nieruchomości, wynajem i usługi związane z prowadzeniem działalności gospodarczej, działalność usługowa komunalna, społeczna 
i indywidualna, pozostała oraz gospodarstwa domowe zatrudniające pracowników), przemysłu i budownictwa oraz wysokotowarowego rolnictwa.

Obszary o większym poziomie bezrobocia są położone na północy i północnym-wschodzie oraz południu i południowym-wschodzie od aglomeracji poznańskiej i środkowo-zachodniej części województwa. Obejmują one głównie trzy podregiony województwa wielkopolskiego: pilski, koniński i kaliski. Problematyka ta wiąże się niewątpliwie z procesem transformacji gospodarczej, w którego rezultacie na znaczeniu traca podregiony oparte na ekstensywnej gospodarce rolnej oraz przemyśle ciężkim i górnictwie. Sytuacja ta tworzy możliwości rozwoju między innymi dla sektora usług rynkowych, w tym usług reklamowo-ogłoszeniowych i prasowo-wydawniczych oraz związanych z rozwojem nowych technologii informatycznych i mediów, zwłaszcza internetu.

Stopę bezrobocia rejestrowanego w poszczególnych podregionach i powiatach województwa wielkopolskiego na koniec 2009 roku przedstawiono w tabeli 8 .

Tabela 8

Stopa bezrobocia rejestrowanego w woj. wielkopolskim i podregionach NTS3

(stan na 31.12.2009)

\begin{tabular}{||l|c|c||}
\hline \multicolumn{1}{|c|}{ Wyszczególnienie } & $\begin{array}{c}\text { Bezrobotni zareje- } \\
\text { strowani ogólem }\end{array}$ & $\begin{array}{c}\text { Stopa bezrobocia } \\
\text { rejestrowanego (\%) }\end{array}$ \\
\hline Województwo wielkopolskie & 2 & 3 \\
\hline Podregion kaliski & $\mathbf{1 3 3} \mathbf{5 6 3}$ & $\mathbf{9 , 1}$ \\
Powiat jarociński & $\mathbf{2 8} \mathbf{6 2 7}$ & $\mathbf{1 0 , 4}$ \\
Powiat kaliski & 3732 & 14,0 \\
Powiat kępiński & 2536 & 8,4 \\
Powiat krotoszyński & 1192 & 4,4 \\
Powiat ostrowski & 3679 & 11,6 \\
Powiat ostrzeszowski & 8167 & 12,9 \\
Powiat pleszewski & 2215 & 9,5 \\
Kalisz (miasto na prawach powiatu) & 3130 & 12,6 \\
\hline Podregion koniński & 3976 & 8,3 \\
Powiat gnieźnieński & $\mathbf{3 5} \mathbf{3 0 2}$ & $\mathbf{1 3 , 6}$ \\
Powiat kolski & 5999 & 11,6 \\
Powiat koniński & 5436 & 14,9 \\
Powiat słupecki & 7214 & 16,0 \\
Powiat turecki & 3823 & 12,7 \\
Powiat wrzesiński & 4175 & 14,2 \\
Konin (miasto na prawach powiatu) & 4301 & 11,7 \\
\hline
\end{tabular}




\begin{tabular}{||l|r|r||}
\hline \multicolumn{1}{|c|}{1} & 2 & 3 \\
\hline Podregion leszczyński & $\mathbf{2 0} \mathbf{7 1 4}$ & $\mathbf{9 , 1}$ \\
Powiat gostyński & 3930 & 12,4 \\
Powiat grodziski & 1796 & 8,6 \\
Powiat kościański & 2584 & 9,3 \\
Powiat leszczyński & 1728 & 8,6 \\
Powiat międzychodzki & 1285 & 9,2 \\
Powiat nowotomyski & 1969 & 6,7 \\
Powiat rawicki & 3172 & 11,8 \\
Powiat wolsztyński & 1694 & 6,9 \\
Leszno (miasto na prawach powiatu) & 2556 & 7,7 \\
\hline Podregion pilski & $\mathbf{2 2} \mathbf{8 3 3}$ & $\mathbf{1 4 , 6}$ \\
Powiat chodzieski & 2853 & 15,5 \\
Powiat czarnkowsko-trzcianecki & 5253 & 15,6 \\
Powiat pilski & 5974 & 10,6 \\
Powiat wagrowiecki & 4168 & 17,0 \\
Powiat złotowski & 4585 & 19,8 \\
\hline Podregion poznański & $\mathbf{1 5 9 0 9}$ & $\mathbf{6 , 6}$ \\
Powiat obornicki & 2034 & 9,9 \\
Powiat poznański & 4846 & 3,5 \\
Powiat szamotulski & 3803 & 11,1 \\
Powiat średzki & 3130 & 13,4 \\
Powiat śremski & 2096 & 9,0 \\
\hline Podregion miasto Poznań & $\mathbf{1 0} \mathbf{1 7 8}$ & $\mathbf{3 , 2}$ \\
\hline \hline
\end{tabular}

Źródło: Biuletyn statystyczny województwa wielkopolskiego, Poznań, luty 2010, s. 72.

Z problematyką bezrobocia wiąże się w szczególności liczba zarejestrowanych podmiotów gospodarczych, które ograniczają rozmiary bezrobocia poprzez tworzenie nowych miejsc pracy i zwiększanie dochodu zarówno państwa, jak i samorządu terytorialnego. Liczba podmiotów gospodarczych w Wielkopolsce systematycznie rośnie, na przykład w latach 2000-2008 według danych Głównego Urzędu Statystycznego wzrosła z 294,4 tys. do 361 tys., czyli prawie o $23 \%$.

Liczbę firm w poszczególnych podregionach województwa wielkopolskiego przypadających na 10000 mieszkańców możemy nazwać wskaźnikiem inicjatywy gospodarczej. Największym dysponują następujące podregiony: miasto Poznań, poznański i leszczyński. Następne w kolejności są podregiony kaliski, koniński i pilski (tab. 9).

Według ocen ekonomicznych najwyższą atrakcyjnością inwestycyjną dla działalności przemysłowej dysponują podregiony miasto Poznań i poznański, przeciętną - koniński i leszczyński, zaś niską - kaliski, a naj- 
$\frac{9}{6}$

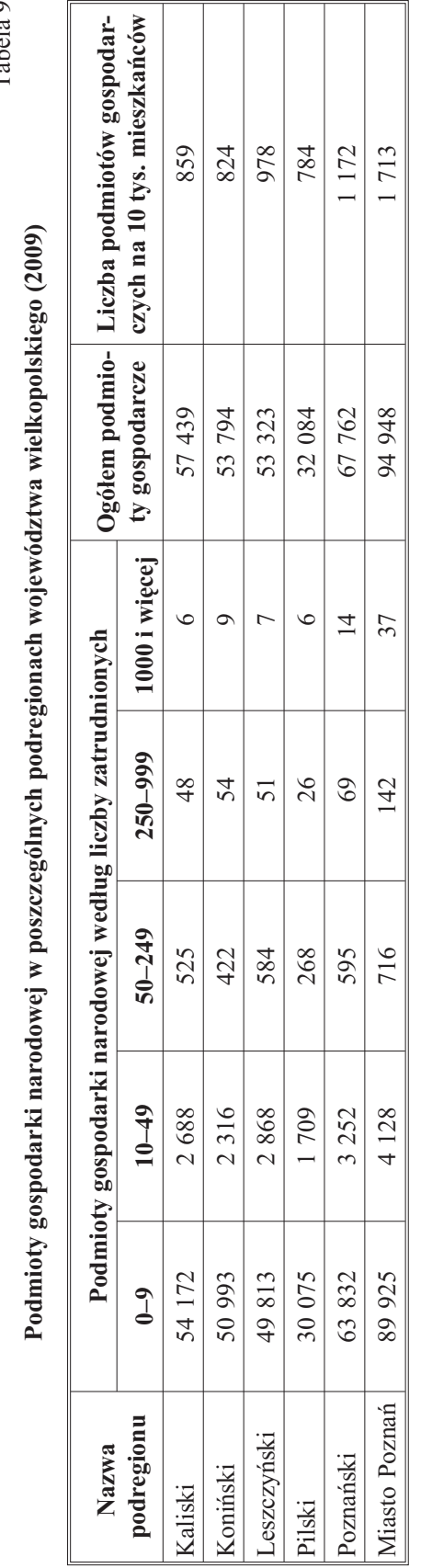


niższą pilski ${ }^{18}$. Nieco inaczej przedstawia się sytuacja poszczególnych podregionów ze względu na ich atrakcyjność dla działalności zaawansowanej technologicznie. Najwyższym wskaźnikiem atrakcyjności w tym obszarze wykazują się podregiony: miasto Poznań i poznański, wysokim - podregion koniński, przeciętnym - kaliski i leszczyński, zaś niskim - pilski $^{19}$.

Dochody ludności stanowią ważny wskaźnik ich możliwości nabywczych i konsumpcyjnych, objawiających się także w dziedzinie zakupu usług medialnych, w tym dostępu do telewizji satelitarnej i szerokopasmowego internetu oraz korzystania z szeroko rozumianych usług edukacyjnych, kulturalnych, turystyczno-krajoznawczych, rozrywkowych, reklamowo-ogłoszeniowych i informacyjnych, wchodzi tutaj w grę także konsumpcja odpłatnej prasy i telewizji lokalnej. Przodującymi podregionami pod względem wysokości miesięcznego wynagrodzenia brutto są dwa podregiony: miasto Poznań i poznański. Następnie podregiony koniński i pilski. Natomiast stosunkowo najmniejsze wynagrodzenie otrzymują osoby zatrudnione w podregionach kaliskim i leszczyńskim. Problematyka ta z punktu widzenia rozwoju mediów lokalnych wiąże się między innymi ze wskaźnikami popytu na lokalną prasę bezpłatną, która może zaspokajać potrzeby mieszkańców podregionów uboższych, o mniejszej sile nabywczej ludności.

W tabeli 10 zebrano dane dotyczące podziału terytorialnego i administracyjnego województwa wielkopolskiego w układzie wyodrębnionych na jego obszarze 6 podregionów.

Tabela 10

Województwo wielkopolskie według podziału terytorialnego w układzie podregionów (2010)

\begin{tabular}{||c|c|c|c|c|c|c||}
\hline \multirow{2}{*}{ Wyszzcególnienie } & \multicolumn{6}{|c||}{ Podregiony } \\
\cline { 2 - 7 } & $\begin{array}{c}\text { kaliski } \\
\text { PL416 }\end{array}$ & $\begin{array}{c}\text { koniński } \\
\text { PL414 }\end{array}$ & $\begin{array}{c}\text { leszczyński } \\
\text { PL417 }\end{array}$ & $\begin{array}{c}\text { pilski } \\
\text { PL411 }\end{array}$ & $\begin{array}{c}\text { poznański } \\
\text { PL418 }\end{array}$ & $\begin{array}{c}\text { Miasto Poznań } \\
\text { PL415 }\end{array}$ \\
\hline 1 & 2 & 3 & 4 & 5 & 6 & 7 \\
\hline $\begin{array}{l}\text { Liczba powiatów } \\
\text { wchodzących w skład } \\
\text { podregionu ogółem }\end{array}$ & 8 & 7 & 9 & 5 & 5 & 1 \\
\hline \hline
\end{tabular}

18 Atrakcyjność inwestycyjna województw i podregionów Polski w 2009 roku, pod red. M. Nowickiego, Konrad Adenauer Stiftung, Instytut Badań nad Gospodarką Rynkowa, Warszawa 2009, s. 22.

${ }^{19}$ Ibidem, s. 35. 


\begin{tabular}{||l|c|c|c|c|c|c||}
\hline \multicolumn{1}{|c|}{1} & 2 & 3 & 4 & 5 & 6 & 7 \\
\hline $\begin{array}{l}\text { Liczba powiatów } \\
\text { ziemskich }\end{array}$ & 7 & 6 & 8 & 5 & 5 & - \\
\hline $\begin{array}{l}\text { Liczba powiatów } \\
\text { grodzkich }\end{array}$ & 1 & 1 & 1 & 0 & 0 & 1 \\
\hline Liczba gmin ogółem & 50 & 58 & 43 & 37 & 37 & 1 \\
\hline Liczba gmin wiejskich & 32 & 34 & 17 & 18 & 16 & - \\
\hline $\begin{array}{l}\text { Liczba gmin miej- } \\
\text { sko-wiejskich }\end{array}$ & 15 & 19 & 24 & 14 & 18 & - \\
\hline Liczba gmin miejskich & 2 & 4 & 1 & 5 & 3 & - \\
\hline $\begin{array}{l}\text { Liczba gmin miejskich } \\
\text { na prawach powiatu }\end{array}$ & 1 & 1 & 1 & 0 & 0 & 1 \\
\hline
\end{tabular}

Źródlo: Ludność. Stan i struktura w przekroju terytorialnym. Stan w dniu 31 XII 2009 r., Główny Urząd Statystyczny, Warszawa 2010.

Poniżej przedstawimy krótką charakterystykę poszczególnych sześciu podregionów województwa wielkopolskiego, odwołując się do podziału statystycznego NTS3.

\section{Podregion kaliski (PL416 ${ }^{20}$ )}

Na podregion kaliski, wchodzący w skład województwa wielkopolskiego, składa się 8 następujących jednostek osadniczych terytorialnego i administracyjnego podziału kraju: 1) powiat jarociński, 2) powiat kaliski, 3) miasto Kalisz (na prawach powiatu), 4) powiat kępiński, 5) powiat krotoszyński, 6) powiat ostrowski, 7) powiat ostrzeszowski, 8) powiat pleszewski.

Jest to czwarty pod względem powierzchni podregion województwa wielkopolskiego $\left(5784 \mathrm{~km}^{2}\right)$. Natomiast pod względem liczby powiatów wchodzących w jego skład zajmuje drugie miejsce po podregionie leszczyńskim. Natomiast pod względem liczby ludności zajmuje pierwsze miejsce wśród podregionów województwa wielkopolskiego $(19,6 \%)$. Według miejsca zamieszkania ludności podregion kaliski charakteryzuje się przewagą mieszkańców wsi (52\%). W jego skład wchodzi łącznie 50 gmin, w tym 32 gminy wiejskie, 15 gmin miejsko-wiejskich, 2 gminy

20 Jest to oficjalny kod NTS, jakim oznaczono ten podregion według następującego schematu: PL oznacza Polskę, następna cyfra, czyli 4 oznacza poziom makroregionu północno-zachodniego (NTS1), cyfra 1 oznacza poziom regionu (NTS2), czyli województwa wielkopolskiego, cyfra 6 oznacza poziom podregionu (NTS3), w tym wypadku podregionu kaliskiego. 
miejskie (Ostrów Wlkp. i Sulmierzyce) oraz gmina miejska na prawach powiatu (Kalisz). W miastach występuje większa przewaga kobiet nad mężczyznami (52\%) niż na wsi (50,3\%). Prawie 16\% ludności mieszka w stolicy podregionu, Kaliszu, który jest ważnym ośrodkiem gospodarczym i kulturalnym podregionu. W Kaliszu i powiecie ziemskim mieszka ponad 28\% ludności podregionu. Drugim pod tym względem mikroregionem jest powiat ostrowski wraz z miastem Ostrów Wlkp., którego potencjał ludnościowy stanowi $24 \%$ potencjału podregionu kaliskiego. Jak widać te trzy jednostki podziału terytorialnego składają się na ponad połowę potencjału ludnościowego podregionu kaliskiego, co stanowi o ich przewadze, a nawet dominacji w wielu innych dziedzinach, między innymi pod względem ilości i różnorodności inicjatyw prasowo-wydawniczych. Produkt krajowy brutto na osobę wytworzony w podregionie kaliskim w 2007 roku wynosił 23599 zl, co plasowało podregion na piątym miejscu w Wielkopolsce. Jeżeli chodzi o liczbę mieszkańców podregionu to $\mathrm{w}$ sumie ulega ona systematycznemu wzrostowi, niemniej występują obszary o ujemnym saldzie przyrostu, do których należy stolica podregionu Kalisz (w latach 2000-2009 liczba ludności Kalisza zmniejszyła się o ponad 2,8\%). Zauważa się jednak niewielką presję zasiedleniową, obejmującą powiat ziemski kaliski, którego liczba ludności w latach 2000-2009 wzrosła o 1,83\%.

Do ważniejszych ośrodków prasowo-wydawniczych podregionu kaliskiego należą w szczególności: Kalisz, Krotoszyn, Ostrów Wielkopolski, Jarocin, Pleszew, Ostrzeszów, Kępno.

\section{Podregion koniński (PL414)}

Na podregion koniński, wchodzący w skład województwa wielkopolskiego, składa się 7 następujących jednostek osadniczych terytorialnego i administracyjnego podziału kraju: 1) powiat gnieźnieński, 2) powiat kolski, 3) miasto Konin (na prawach powiatu), 4) powiat koniński, 5) powiat słupecki, 6) powiat turecki, 7) powiat wrzesiński.

Jest to drugi pod względem powierzchni podregion województwa wielkopolskiego $\left(6397 \mathrm{~km}^{2}\right)$. Jednak pod względem liczby powiatów wchodzących w jego skład zajmuje trzecie miejsce. Natomiast pod względem liczby ludności zajmuje drugie miejsce wśród podregionów województwa wielkopolskiego (ponad 19\%). Według miejsca zamieszkania ludności podregion charakteryzuje się przewagą mieszkańców wsi (52\%). W jego skład wchodzi łącznie 58 gmin, w tym 34 gminy wiejskie, 19 gmin miejsko-wiejskich, 4 gminy miejskie (Gniezno, Koło, 
Słupca, Turek) oraz gmina na prawach powiatu (Konin). W miastach występuje większa przewaga kobiet nad mężczyznami (52\%) niż na wsi $(50,3 \%)$. Ponad $12 \%$ ludności mieszka w stolicy podregionu, Koninie, który jest ważnym ośrodkiem gospodarczym i kulturalnym podregionu. W Koninie i powiecie ziemskim mieszka prawie 1/3 (32\%) ludności podregionu. Następnymi pod tym względem mikroregionami są w kolejności: powiat kolski, którego potencjał ludnościowy stanowi ponad 13\% potencjału podregionu konińskiego oraz powiat turecki $(12,7 \%)$ i powiat słupecki $(8,9 \%)$. Jak widać te cztery jednostki podziału terytorialnego składają się na ponad połowę potencjału ludnościowego podregionu konińskiego, co stanowi o ich przewadze, a nawet dominacji w wielu innych dziedzinach, między innymi pod względem ilości i różnorodności inicjatyw prasowo-wydawniczych. Produkt krajowy brutto na osobę wytworzony w podregionie konińskim w 2007 roku wynosił 23288 zł, co plasowało podregion na szóstym miejscu w Wielkopolsce. Jeżeli chodzi o liczbę mieszkańców podregionu, to w sumie ulega ona systematycznemu wzrostowi, niemniej występują obszary o ujemnym saldzie przyrostu, do których należy stolica podregionu Konin (w latach 2000-2009 liczba mieszkańców Konina zmniejszyła się o ponad 3,7\%) oraz powiaty kolski, słupecki i turecki. Mimo tego widać jednak wyraźną presję zasiedleniową, obejmującą powiat ziemski koniński, którego liczba ludności w latach 2000-2009 wzrosła o 4,5\%.

Do ważniejszych ośrodków prasowo-wydawniczych podregionu konińskiego należą w szczególności: Września, Słupca, Konin, Koło, Gniezno, Turek.

\section{Podregion leszczyński (PL417)}

Na podregion leszczyński, wchodzący w skład województwa wielkopolskiego, składa się 9 następujących jednostek osadniczych terytorialnego i administracyjnego podziału kraju: 1) powiat gostyński, 2) powiat grodziski, 3) powiat kościański, 4) powiat leszczyński, 5) miasto Leszno (na prawach powiatu), 6) powiat międzychodzki, 7) powiat nowotomyski, 8) powiat rawicki, 9) powiat wolsztyński.

Jest to trzeci pod względem powierzchni podregion województwa wielkopolskiego $\left(5996 \mathrm{~km}^{2}\right)$. Natomiast pod względem liczby powiatów wchodzących w jego skład dzierży pierwsze miejsce. Natomiast pod względem liczby ludności zajmuje piąte miejsce wśród podregionów województwa wielkopolskiego (16\%). Według miejsca zamieszkania ludności podregion charakteryzuje się przewagą mieszkańców wsi (54\%). 
W jego skład wchodzą łącznie 43 gminy, w tym 17 gmin wiejskich, 24 gminy miejsko-wiejskie, gmina miejska (Kościan) oraz gmina miejska na prawach powiatu (Leszno). W miastach występuje przewaga kobiet nad mężczyznami (52\%), natomiast na wsi jest niemal równowaga. Prawie $12 \%$ ludności mieszka w stolicy podregionu, Lesznie, który jest ważnym ośrodkiem gospodarczym i kulturalnym podregionu. W Lesznie i powiecie ziemskim mieszka ponad 1/5 (21\%) ludności podregionu. Następnymi pod tym względem mikroregionami są w kolejności: powiat kościański, którego potencjał ludnościowy stanowi ponad 14\% potencjału podregionu leszczyńskiego oraz powiat gostyński (prawie 14\%) i powiat nowotomyski (ponad 13\%). Jak widać te pięć jednostek podziału terytorialnego składa się na ponad $3 / 5$ potencjału ludnościowego podregionu konińskiego, co stanowi o ich przewadze, a nawet dominacji w wielu innych dziedzinach, między innymi pod względem ilości i różnorodności inicjatyw prasowo-wydawniczych. Produkt krajowy brutto na osobę wytworzony w podregionie leszczyńskim w 2007 roku wynosił $25635 \mathrm{zł}$, co plasowało podregion na trzecim miejscu w Wielkopolsce. Jeżeli chodzi o liczbę mieszkańców podregionu, to w sumie ulega ona systematycznemu wzrostowi i nie występują na tym obszarze jednostki o ujemnym saldzie przyrostu w latach 2000-2009. Niemniej widać wyraźną presję zasiedleniową, obejmującą powiat ziemski leszczyński, którego ludność wzrosła w latach 2000-2009 prawie o 7,3\%.

Do ważniejszych ośrodków prasowo-wydawniczych podregionu leszczyńskiego należą w szczególności: Leszno, Nowy Tomyśl, Grodzisk Wielkopolski, Międzychód, Gostyń, Rawicz, Kościan, Wolsztyn.

\section{Podregion pilski (PL411)}

$\mathrm{Na}$ podregion pilski, wchodzący w skład województwa wielkopolskiego, składa się 5 następujących jednostek osadniczych terytorialnego i administracyjnego podziału kraju: 1) powiat chodzieski, 2) powiat czarnkowsko-trzcianecki, 3) powiat pilski, 4) powiat wagrowiecki, 5) powiat złotowski.

Jest to największy pod względem powierzchni podregion województwa wielkopolskiego $\left(6459 \mathrm{~km}^{2}\right)$. Pod względem liczby powiatów wchodzących w jego skład zajmuje czwarte miejsce wraz z podregionem poznańskim. Pod względem liczby ludności zajmuje ostatnie miejsce wśród podregionów województwa wielkopolskiego (12\%). Według miejsca zamieszkania ludności podregion pilski charakteryzuje się przewagą mieszkańców miasta (54\%). W jego skład wchodzi łącznie 37 
gmin, w tym 18 gmin wiejskich, 14 gmin miejsko-wiejskich i 5 gmin miejskich (Chodzież, Czarnków, Piła, Wagrowiec, Złotów). W miastach występuje przewaga kobiet nad mężczyznami (52\%), natomiast na wsi jest niewielka przewaga mężczyzn (50,5\%). Ponad 18\% ludności mieszka w stolicy podregionu, Pile, która jest ważnym ośrodkiem gospodarczym i kulturalnym podregionu. W Pile i powiecie ziemskim mieszka prawie 34\% ludności podregionu. Drugim pod tym względem mikroregionem jest powiat czarnkowsko-trzcianecki, którego potencjał ludnościowy stanowi ponad $21 \%$ potencjału podregionu pilskiego. Jak widać te trzy jednostki podziału terytorialnego składają się na ponad połowę potencjału ludnościowego podregionu pilskiego, co stanowi o ich przewadze, a nawet dominacji w wielu innych dziedzinach, między innymi pod względem ilości i różnorodności inicjatyw prasowo-wydawniczych. Produkt krajowy brutto na osobę wytworzony w podregionie pilskim w 2007 roku wynosił 24598 zł, co plasowało podregion na czwartym miejscu w Wielkopolsce. Jeżeli chodzi o liczbę mieszkańców podregio$\mathrm{nu}$, to w sumie ulega ona systematycznemu wzrostowi i nie występują na tym obszarze jednostki o ujemnym saldzie przyrostu w latach 2000-2009. Niemniej widać niewielką presję zasiedleniową, obejmującą powiat ziemski pilski, którego liczba ludności w latach 2000-2009 wzrosła o $0,85 \%$.

Do ważniejszych ośrodków prasowo-wydawniczych podregionu pilskiego należą w szczególności: Wagrowiec, Czarnków, Trzcianka, Chodzież, Złotów, Piła.

\section{Podregion poznański (PL418)}

Na podregion poznański, wchodzący w skład województwa wielkopolskiego, składa się 5 następujących jednostek osadniczych terytorialnego i administracyjnego podziału kraju: 1) powiat obornicki, 2) powiat poznański, 3) powiat szamotulski, 4) powiat średzki, 5) powiat śremski.

Jest to piąty pod względem powierzchni podregion województwa wielkopolskiego $\left(4929 \mathrm{~km}^{2}\right.$ ). Podregion poznański pod względem liczby powiatów wchodzących w jego skład zajmuje czwarte miejsce wraz z podregionem pilskim. Natomiast pod względem liczby ludności zajmuje trzecie miejsce wśród podregionów województwa wielkopolskiego (prawie 17\%). Według miejsca zamieszkania ludności podregion poznański charakteryzuje się przewagą mieszkańców wsi (prawie 56\%). W jego skład wchodzi łącznie 37 gmin, w tym 16 gmin wiejskich, 18 gmin miejsko-wiejskich i 3 gminy miejskie (Luboń, Obrzycko, Puszczyko- 
wo). W miastach występuje większa przewaga kobiet nad mężczyznami (prawie 52\%) niż na wsi (50,5\%). Ponad 55\% ludności podregionu mieszka w powiecie poznańskim. Drugim pod tym względem mikroregionem jest powiat szamotulski (ponad 15\%). Jak widać te dwie jednostki podziału terytorialnego składają się na ponad $2 / 3$ potencjału ludnościowego podregionu poznańskiego, co stanowi o ich przewadze, a nawet dominacji w wielu innych dziedzinach, między innymi pod względem ilości i różnorodności inicjatyw prasowo-wydawniczych. Produkt krajowy brutto na osobę wytworzony w podregionie poznańskim w 2007 roku wynosił 34624 zł, co plasowało podregion na drugim miejscu w Wielkopolsce. Jeżeli chodzi o liczbę mieszkańców podregio$\mathrm{nu}$, to w sumie ulega ona systematycznemu i dynamicznemu wzrostowi. Nie występują na tym obszarze jednostki o ujemnym saldzie przyrostu w latach 2000-2009. Niemniej widać wyraźną presję zasiedleniową, obejmującą powiat ziemski poznański, którego liczba ludności w latach 2000-2009 wzrosła aż o 22,55\%. Podregion poznański jest zaliczany do tzw. zaplecza metropolii i silnych ośrodków ponadlokalnych ${ }^{21}$.

Do ważniejszych ośrodków prasowo-wydawniczych podregionu poznańskiego należą w szczególności: powiat poznański, Środa Wielkopolska, Szamotuły, Śrem, Oborniki Wielkopolskie.

\section{Podregion miasto Poznań (PL415)}

Na podregion miasto Poznań, stolicę województwa wielkopolskiego, składa się 5 tzw. dzielnic, w których znajdują się delegatury Urzędu Miasta Poznania (Grunwald, Jeżyce, Nowe Miasto, Stare Miasto, Wilda ${ }^{22}$ ).

Jest to najmniejszy pod względem powierzchni podregion województwa wielkopolskiego $\left(262 \mathrm{~km}^{2}\right)$. Natomiast pod względem wielkości produktu krajowego brutto na osobę wytworzonego w podregionie w 2007 roku, który wynosił 62422 zł, zajmuje pierwsze miejsce wśród podregionów w Wielkopolsce.

21 R. Górecki, T. Kot, Identyfikacja obszarów problemowych i strategicznej interwencji jako przyklad partnerskiej realizacji projektu badawczego na potrzeby Krajowej Strategii Rozwoju Regionalnego, Departament Programów Ponadregionalnych, Ministerstwo Rozwoju Regionalnego, Toruń, 7-8 grudnia 2009, s. 13.

${ }^{22}$ Należy nadmienić, iż administracyjny podział Poznania na 5 wymienionych dzielnic istniał od 1955 roku. Jest to jednak podział już tylko historyczny, który współcześnie nie ma żadnego umocowania prawnego. Zob. Wielka księga miasta Poznania, red. K. Matusiak, Poznań 1994, s. 203-206. 
Na obszarze Poznania wyodrębniono 69 terytorialnych wewnętrznych jednostek pomocniczych (osiedli). Osiedle jest względnie spójnym obszarem w szczególności pod względem terytorialnym i funkcjonalnym oraz o wspólnym dziedzictwie historycznym i tradycjach lokalnych. Pierwsze osiedla powstały z inicjatywy Komitetów Obywatelskich „Solidarność" na początku lat dziewięćdziesiątych ${ }^{23}$. W następnych latach powoływano kolejne jednostki pomocnicze (tab. 11).

Biorąc pod uwagę kryterium liczby mieszkańców osiedli, należy zauważyć, iż około $45 \%$ tych jednostek liczy do 5 tys. mieszkańców, około $31 \%$ powyżej 5 tys. do 10 tys., około $15 \%$ mieści się w przedziale powyżej 10 tys. do 20 tys., natomiast powyżej 20 tys. mieszkańców ma około 9\% osiedli. Od 2011 roku podział Poznania na osiedla uległ radykalnej zmianie, drastycznie zmniejszyła się bowiem liczba osiedli, co wynika z postanowień Rady Miasta ${ }^{24}$.

Podregion miasto Poznań pod względem liczby ludności zajmuje czwarte miejsce wśród sześciu podregionów województwa wielkopolskiego (ponad 16\%). Miasto może się poszczycić różnorodnością inicjatyw prasowo-wydawniczych, zaspokajających potrzeby informacyjne pluralistycznego odbiorcy wielkomiejskiego.

Poznań jest jednym z najstarszych i największych polskich miast. Pierwsze wzmianki o Poznaniu pochodzą z 970 roku, jednak formalnie prawa miejskie Poznań otrzymał dopiero w 1253 roku, w którym król Polski Przemysł II ustanowił tutaj swoją stolicę. W Poznaniu w 968 roku książę Mieszko I założył pierwsze na ziemiach polskich biskupstwo.

Obecnie Poznań stanowi centralną część tzw. aglomeracji poznańskiej $^{25}$, obejmującej obszar 22 sąsiednich gmin, powiązanych z Poznaniem wielostronnymi związkami funkcjonalnymi w sferze zarówno społecznej i komunalnej, jak gospodarczej ${ }^{26}$. Miasto Poznań jest zaliczane do

23 Uchwała Nr XLIII/224/91 Rady Miasta Poznania z dnia 19.11.1991 roku w sprawie powołania Osiedla Smochowice stanowiła pierwszy tego typu akt prawa miejscowego.

24 Zob. Uchwała Nr LXIX/941/V/2010 Rady Miasta Poznania z dnia 16 marca 2010 r.

25 Szerzej na ten temat zobacz: Aglomeracja Poznańska. Profile miast, gmin i powiatu, pod red. T. Kaczmarka, Ł. Mikuły, Poznań, czerwiec 2010.

26 W skład aglomeracji poznańskiej wchodzą następujące 23 gminy: Buk, Czerwonak, Dopiewo, Kaźmierz, Kleszczewo, Komorniki, Kostrzyn, Kórnik, Luboń, Mosina, Murowana Goślina, Oborniki, Pobiedziska, Poznań, Puszczykowo, Rokietnica, Stęszew, Suchy Las, Swarzędz, Szamotuły, Śrem, Środa Wlkp., Tarnowo Podgórne. 


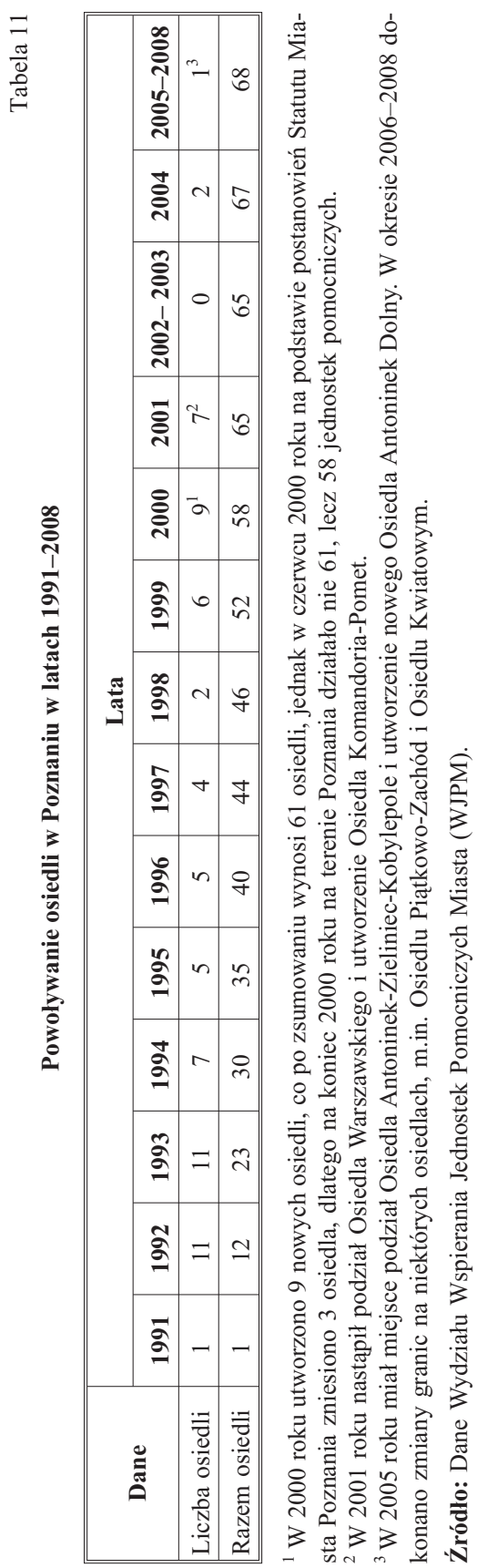


kategorii tzw. krajowych ośrodków rozwoju (obok Łodzi, Krakowa, Szczecina, Wrocławia i trójmiasta) ${ }^{27}$.

Potencjał terytorialny, ludnościowy, gospodarczy i naukowy aglomeracji poznańskiej na tle województwa wielkopolskiego zilustrowano w tabeli 12 .

Tabela 12

Potencjal aglomeracji poznańskiej na tle województwa wielkopolskiego (2008)

\begin{tabular}{||l|c|c|c||}
\hline \multicolumn{1}{|c|}{ Wyszczególnienie } & $\begin{array}{c}\text { Aglomeracja } \\
\text { poznańska }\end{array}$ & $\begin{array}{c}\text { Województwo } \\
\text { wielkopolskie }\end{array}$ & $\begin{array}{c}\text { Udzial aglomeracji } \\
\text { poznańskiej w woje- } \\
\text { wództwie (\%) }\end{array}$ \\
\hline Powierzchnia & $2743 \mathrm{~km}^{2}$ & $29827 \mathrm{~km}^{2}$ & 9,2 \\
\hline Ludność & 949195 & 3403174 & 27,9 \\
\hline Miejsca pracy & 334179 & 840085 & 39,8 \\
\hline Podmioty gospodarcze prywatne & 141315 & 351327 & 40,2 \\
\hline Spółki z kapitałem zagranicznym & 3613 & 5574 & 64,8 \\
\hline Studenci & 142228 & 173945 & 81,8 \\
\hline Dochody podatkowe jst & $1897 \mathrm{mln}$ zł & $4385 \mathrm{mln}$ zł & 43,3 \\
\hline
\end{tabular}

Źródło: GUS.

Poznań jest współcześnie znaczącym ośrodkiem gospodarczym, naukowym i kulturalnym w kraju i historyczną stolicą Wielkopolski. Od 1 stycznia 1999 roku Poznań ma status gminy miejskiej na prawach powiatu grodzkiego. Na dzień 31 grudnia 2009 roku Poznań zamieszkiwało 554221 osób. W ogólnej populacji mieszkańców przeważały kobiety (ponad 53\%). Liczba mieszkańców podregionu zmniejszała się systematycznie w latach 2000-2009 (z 582,3 tys. do 554,2 tys., czyli o ponad 4,7\%). Niemniej widać wyraźną presję zasiedleniowa, obejmującą powiat ziemski poznański, którego liczba ludności w latach 2000-2009 wzrosła o prawie 7,3\%. W 2009 roku ludność w wieku produkcyjnym stanowiła 66\% mieszkańców Poznania (na 100 osób w wieku produkcyjnym przypadało 51 osób w wieku nieprodukcyjnym), a stopa bezrobocia wynosiła $3,2 \%$ i była najniższa w województwie wielkopolskim.

27 R. Górecki, T. Kot, Identyfikacja obszarów problemowych i strategicznej interwencji jako przykład partnerskiej realizacji projektu badawczego na potrzeby Krajowej Strategii Rozwoju Regionalnego, Departament Programów Ponadregionalnych, Ministerstwo Rozwoju Regionalnego, Toruń, 7-8 grudnia 2009, s. 12. 
Mówiąc o jednostkach pomocniczych Poznania, czyli osiedlach, nie wspomniano o ich inicjatywach prasowo-wydawniczych, które są bardzo liczne i różnorodne. W tabeli 13 zgromadzono bliższe informacje o tych niezmiernie ciekawych przejawach działalności prasowo-wydawniczej na poziomie pojedynczego osiedla.

Pisma osiedlowe wydawane przez samorządy osiedlowe w Poznaniu (stan na 04.2008)

\begin{tabular}{|c|c|c|}
\hline Lp. & Nazwa osiedla & Tytul wydawnictwa \\
\hline 1. & Kopernika-Raszyn & „Informator Osiedlowy” \\
\hline 2. & Św. Łazarza & „Wieści Łazarskie” \\
\hline 3. & Ks. Jerzego Popiełuszki & „Gazetka Osiedlowa” \\
\hline 4. & Targowe & „Nasze Osiedle-TARGOWE” \\
\hline 5. & Junikowo & „Gazetka Junikowska” \\
\hline 6. & Kwiatowe & „Echo Osiedla Kwiatowego” \\
\hline 7. & Stanisława Przybyszewskiego & $\begin{array}{l}\text { „Gazetka Osiedlowa Rady Osiedla Stanisława Przy- } \\
\text { byszewskiego" }\end{array}$ \\
\hline 8. & Ogrody & „Kurier Ogrodowy” \\
\hline 9. & Jeżyce & „Nasze Jeżyce” \\
\hline 10. & Krzyżowniki-Smochowice & „Nasze Krzyżowniki ze Smochowicami” \\
\hline 11. & Żegrze & „Głos Żegrza” \\
\hline 12. & Komandoria-Pomet & „BYĆ” \\
\hline 13. & Starołęka-Minikowo-Marlewo & „Nasza Starołęka” \\
\hline 14. & Ostrów Tumski-Śródka-Zawady & „Wokół Śródki” \\
\hline 15. & Rataje nad Wartą & „Rataje nad Wartą" \\
\hline 16. & Chartowo & „Głos Chartowa” \\
\hline 17. & Starołęka Mała & „Starołęka Mała” \\
\hline 18. & Zielone Rataje & „Zielona Gazetka” \\
\hline 19. & Zwycięstwa & „Informator Osiedla Zwycięstwa” \\
\hline 20. & Śródmieście & „Wieści ze Śródmieścia” \\
\hline 21. & Piątkowo-Zachód & „Biuletyn Informacyjny Osiedla” \\
\hline 22. & Rybaki-Piaski & „Biuletyn Rady Osiedla Rybaki-Piaski” \\
\hline 23. & Stare Winogrady & „Kwartalnik Rady Osiedla Stare Winogrady” \\
\hline 24. & Wichrowe Wzgórze & „Wiadomości Osiedla Wichrowe Wzgórze” \\
\hline 25 . & Radojewo & „Biuletyn Informacyjny Osiedla Radojewo” \\
\hline 26. & Umultowo & „Panorama Umultowo (wykup stron w gazecie)” \\
\hline 27. & Świerczewo & „Kwartalnik Osiedla Świerczewo” \\
\hline
\end{tabular}

Źródło: Opracowano na podstawie danych WJPM. 
Podregion miasto Poznań należy do największych w Wielkopolsce ośrodków prasowo-wydawniczych, co jest skądinąd zrozumiałe choćby z powodu jego potencjału ludnościowego i naukowo-kulturowego oraz długoletnich tradycji w tej dziedzinie. Znajdują się tutaj siedziby wydawców prasy regionalnej, zarówno uniwersalnej, jak i specjalistycznej oraz środowiskowej, w tym naukowej, popularnonaukowej, regionalistycznej, branżowej. Jest to bodaj największy w Wielkopolsce, być może nawet w Polsce, ośrodek prasy osiedlowej - praktycznie na każdym osiedlu poznańskim ukazuje się jakaś postać biuletynu czy informatora osiedlowego. Jest to zapewne konsekwencja poznańskich tradycji samorządności lokalnej, tutaj bowiem mieści się również siedziba Związku Miast Polskich, którego Poznań był jednym z inicjatorów.

Zaprezentowany wyżej podział terytorium województwa wielkopolskiego umożliwia m.in. zgromadzenie informacji pomocnych przy analizie, abstrahowaniu oraz badaniach porównawczych rozwoju prasy lokalnej na poszczególnych wyodrębnionych terytorialnie obszarach i przedstawienie jej ogólnych uwarunkowań demograficzno-terytorialnych oraz społeczno-ekonomicznych i kulturowych. Dane te mogą służyć w szczególności do próby ustalenia tzw. wskaźnika inicjatywy prasowo-wydawniczej $^{28}$, który jest zależny między innymi od takich jednostkowych czynników, jak: liczba i struktura ludności, w tym wskaźnik ludności w wieku nieprodukcyjnym (zarówno przed-, jak i poprodukcyjnym), gęstość zaludnienia, współczynnik urbanizacji, status gospodarczy i poziom bezrobocia, dochody ludności, stan rozwoju bazy edukacyjno-oświatowej, kulturalnej, sportowej, rekreacyjnej, przeobrażenia historyczne, w tym zmiany terytorialne i przynależności administracyjnej oraz lokalne tradycje prasowo-wydawnicze.

28 Wskaźnik inicjatywy prasowo-wydawniczej jest stosunkiem ogólnej liczby tytułów prasy lokalnej zainicjowanych w podregionie w danym okresie do liczby jego mieszkańców. Oznacza zatem liczbę mieszkańców przypadających na jeden tytuł prasy lokalnej. Dlatego obrazuje głównie różnice jakościowe, jakie zachodzą pomiędzy poszczególnymi podregionami województwa wielkopolskiego. Im wskaźnik jest mniejszy, tym większy jest poziom inicjatywy prasowo-wydawniczej w danym podregionie. Wskaźnik ten może być miernikiem inicjatywy prasowo-wydawniczej w danym roku lub też odnosić się do wybranego do badań interwału czasowego. 


\title{
The structural composition of Wielkopolska as a local press research field
}

\begin{abstract}
Summary
The author presents the analysis of the current territorial structure of Wielkopolska as a potential research field for studies into the local press market and its trends. The contents of the paper comprise a demographic and territorial description of Wielkopolska, including an analysis of the six sub-regions distinguished on the basis of the European Nomenclature of Territorial Units for Statistics (NUTS). The purpose of the paper is to collect information to support the analysis, generalization and comparative examination of the development of the local press in specific areas, and the general presentation of demographic, territorial, socio-economic and cultural conditions. The composition of local press markets depends on such factors as the size and structure of populations, including the proportions of non-productive population (both pre-, and post-production age groups), population density, the rate of urbanization, economic status and levels of unemployment, income, development of educational, cultural, sporting and recreational facilities, historical transformations, including changes in territorial and administrative affiliation, and local press traditions.
\end{abstract}


